JURNAL

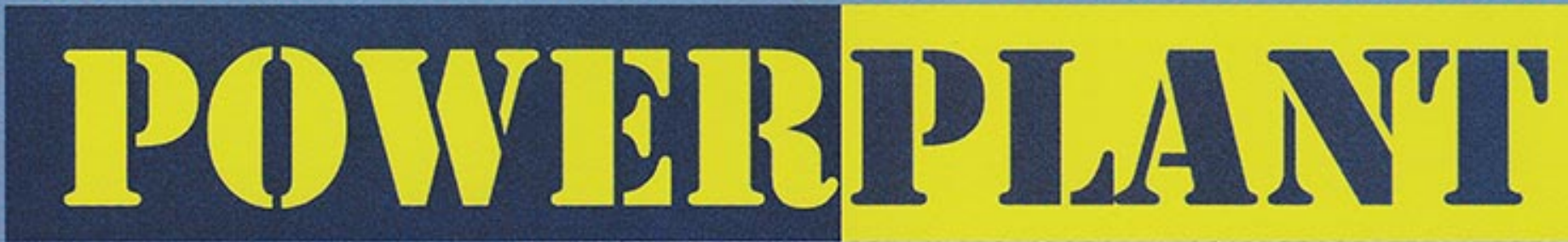

Roswati Nurhasanah

Jasmid Edy

Eza Brian Pradana

\section{Arief Suardi}

Vendy Antono

Al Asyi

Arisma Chairul Syarif Iman Kartolaksono R Jalu Eko Harjono

Nofirman

Yusuf Rasyid

Win Alfalah

Eko Sulistyo

Rahmat Ikhsan

Utami Wahyuningsih

Halim Rusjdi

Eko Sulistiyo

Sahlan

Jumiati

Intan Ratna Sari Yanti

Sri Yayi
Perancangan Boiler Dengan Memanfaatkan Sampah

Kering Untuk Bahan Bakar PLTU Mini 3 kW STT-PLN

Analisis Perbandingan Penggunaan Big Oil Gun dan Tiny Oil Gun terhadap Kosumsi Bahan Bakar Pada Saat Strat Up Unit di PLTU Banten Lontar

Uji Prestasi dan Emisi Diesel Berbahan Bakar Minyak Nabati Murni untuk Pembangkitan Daya di Daerah Terpencil

Pengukuran Suhu Pembakaran di Dalam Boiler : Pirometer Akuistik VS Pirometer Infared

Pengaruh Pemeliharaan Overhoul Turbo Charger

Terhadap Kinerja Mesin Unit VII PLTD Ampenan

Penanggulangan Korosi Pada Pipa Gas Dengan Metode Catodic Protection (Anoda Karbon) PT PGN Solution Area Cengkareng

Analisis Strategi Teknologi PLTS Fotovoltik di Indonesia Terhadap Nilai Eqivalensi dan Pemanfatan Per Wilayah

Pengembangan Model Pembelajaran Berbasis Tutorial Bagi Mahasiswa Teknik Mesin STT PLN

\begin{tabular}{|c|c|c|c|c|c|c|}
\hline III & & $\mathrm{SE}$ & OLAH & INGGI TEV & PLN (STT-PLN) & \\
\hline - $\|||||||||||||||||$ & JURNAL POWERPLANT & VOL. 5 & NO. 1 & HAL, 1.63 & NOVEMBER 2017 & ISSN No :2356-1513 \\
\hline
\end{tabular}




\title{
PENANGGULANGAN KOROSI PADA PIPA GAS DENGAN METODE CATODIC PROTECTION (ANODA KORBAN) PT PGN SOLUTION AREA TANGERANG
}

\author{
Utami Wahyuningsih ${ }^{1)}$, Halim Rusjdi ${ }^{2)}$, dan Eko Sulistiyo ${ }^{3)}$ \\ ${ }^{1,2}$ Jurusan Teknik Mesin, Sekolah Tinggi STT - PLN \\ 1'wahyuningsih_utami@yahoo.com, \\ 2halim.r66@gmail.com, \\ 33ekosalma123@yahoo.com
}

\begin{abstract}
Corrosion is a common problem that often occurs in metals. Corrosion is the damage or degradation of metal due to the redox reaction between a metal with various substances in the environment that produce undesirable compounds. In the event of corrosion, the metal will experience oxidation while the air will experience reduction. Corrosion can be regarded as an electrochemical event between the metal and its environment. Simply, corrosion can occur if there are anodes, cathodes, electrolyte solutions, and metallic contacts between the cathode and the anode. In submarine pipelines, corrosion problems occur frequently for a corrosion-control measure. One of them is by using cathodic protection method using sacrificial anode system (sacrificial anode) and system impressed current (tilt current)
\end{abstract}

Keywords: corrosion, cathodic protection, sacrificial anode, impressed current.

\section{PENDAHULUAN}

Berkembangnya teknologi mempengaruhi manusia di segala bidang, tidak terkecuali pemanfaatan gas bumi untuk menunjang kehidupan masyarakat. Hal ini terlihat dari bertambahnya jumlah pelanggan yang menggunakan tekanan gas dan dibangunnya beberapa stasiun gas di beberapa titik wilayah.

Untuk meneruskan energi baik ini kepada pelanggan yang kebanyakan perusahaan yang bergerak dalam dunia industri dan rumah tangga, maka dibangun jaringan pipa gas dengan memanfaatkan jalur pipa sehingga dapat dimanfaatkan dengan sebaik mungkin.

Jaringan pipa gas ini berfungsi untuk distribusi dan transmisi aliran gas dari sumber menuju pelanggan. Dan pada proses aliran gas tersebut menggunakan Pipa dengan berbagai ukuran dan tekanan yang berbeda-beda yang disesuaikan dengan kondisi yang ada di lapangan dan sering terjadi kasus berupa kebocoran pipa gas yang disebabkan oleh beberapa faktor.

Sistem perpipaan terdiri dari beberapa jaringan pipa yang digunakan sebagai alat distribusi. Sesuai dengan standar teknik perpipaan yang dipakai di Indonesia dan tertuang dalam Surat Keputusan Menteri
Pertambangan dan Energi Nomor 300.K/MPE.38/1997, maka pipa penyalur minyak dan gas bumi harus ditimbun di dalam tanah (Mentamben, 1997). Hal ini sesuai juga dengan standar internasional tentang pemasangan pipa, contohnya ASME B31.8 yang berjudul Gas Transmission and Distribution Piping System (ASME, 2005). Penempatan jaringan pipa dalam tanah dapat menyebabkan korosi pada permukaan pipa, hal ini terjadi karena dalam tanah terdapat mineral-mineral yang dapat menyebabkan atau bahkan memacu terjadinya korosi pada permukaan pipa.

Untuk mengendalikan atau memperlambat terjadinya korosi pada jaringan pipa tersebut maka sistem pengendalian yang dapat dilakukan pada umumnya adalah pemasangan coating dan dilengkapi dengan penerapan metode proteksi katodik.

\section{KAJIAN LITERATUR}

\subsection{Definisi Korosi}

Korosi adalah proses perusakan pada permukaan logam yang disebabkan oleh terjadinya reaksi kimia (reaksi elektrokimia) pada permukaan logam. Pada hakikatnya korosi adalah suatu reaksi dimana suatu logam dioksidasi sebagai akibat dari serangan kimia 
oleh lingkungan (uap air,oksigen di atmosfer, oksida asam yang terlarut dalam ).

Dalam bahasa sehari-hari korosi disebut dengan perkaratan. Kata korosi berasal dari bahasa latin "corrodere" yang artinya pengrusakan logam atau perkaratan.Jadi jelas korosi dikenal sangat merugikan.

Korosi merupakan sistem termodinamika logam dengan lingkungannya, yang berusaha untuk mencapai kesetimbangan. Sistem ini dikatakan setimbang bila logam telah membentuk oksida atau senyawa kimia lain yang lebih stabil.

Korosi merupakan reaksi redoks antara suatu logam dengan berbagai zat di lingkungannya yang menghasilkan senyawa-senyawa yang tak dikehendaki. Dalam bahasa sehari-hari, korosi disebut perkaratan. Contoh korosi yang paling lazim adalah perkaratan besi. Pada peristiwa korosi, logam mengalami oksidasi, sedangkan oksigen (udara) mengalami reduksi. Karat logam umumnya adalah berupa oksida dan karbonat. Rumus kimia karat besi adalah $\mathrm{Fe}_{2} \mathrm{O}_{3}$. $\mathrm{xH}_{2} \mathrm{O}$, suatu zat padat yang berwarna coklatmerah.

Korosi atau perkaratan logam juga dikenal sebagai proses oksidasi sebuah logam dengan udara atau elektrolit lainnya, dimana udara atau elektrolit akan mengalami reduksi, sehingga proses korosi merupakan proses elektrokimia.

\subsection{Jenis Korosi}

Bentuk-bentuk korosi yang umum ditemukan pada korosi logam pipa yaitu;

\section{Uniform Corrosion}

yaitu korosi yang terjadi pada permukaan logam yang berbentuk pengikisan permukaan logam secara merata, sehingga ketebalan logam berkurang sebagai akibat permukaan terkonversi oleh produk karat yang biasanya terjadi pada peralatan-peralatan terbuka. Misalnya permukaan luar pipa.

\section{Pitting Corrosion}

yaitu korosi yang berbentuk lubang-lubang pada permukaan logam karena hancurnya film dari proteksi logam yang disebabkan oleh rate korosi yang berbeda antara satu tempat dengan tempat yang lainnya pada permukaan logam tersebut.

\section{Stress Corrosion Cracking}

yaitu korosi berbentuk retak-retak yang tidak mudah dilihat, terbentuk dipermukaan logam dan berusaha menjalar ke dalam. Ini banyak terjadi pada logam-logam yang banyak mendapat tekanan. Hal ini disebabkan kombinasi dari tegangan tarik dan lingkungan yang korosif sehingga struktur logam melemah.

\section{Errosion Corrosion}

yaitu korosi yang terjadi karena tercegahnya pembentukan film pelindung yang disebabkan oleh kecepatan alir fluida yang tinggi, misalnya abrasi pasir,

\section{Galvanic Corrosion}

yaitu korosi yang terjadi karena terdapat hubungan antara dua metal yang disambung dan terdapat perbedaan potensial antara keduanya.

\section{Crevice Corrosion}

yaitu korosi yang terjadi di sela-sela gasket, sambungan bertindih, sekrup-sekrup atau kelingan yang terbentuk oleh kotoran-kotoran endapan atau timbul dari produk-produk karat.

\section{Selective Leaching}

korosi ini berhubungan dengan melepasnya satu elemen dari Campuran logam. Contoh yang paling mudah adalah desinfication yang melepaskan zinc dari paduan tembaga.

\subsection{Mekanisme Korosi}

Pada umumnya korosi pada logam merupakan reaksi elektrokimia. Raksi elektrokimia adalah suatu reaksi yang memperlihatkan perpindahan. Reaksi ini meliputi reaksi oksidasi dan reaksi reduksi.

Contoh reaksi oksidasi dan reaksi reduksi:

$\mathrm{Zn} \rightarrow \mathrm{Zn}^{2^{+}}+{ }_{2} \mathrm{e}^{-}$(reaksi oksidasi)

$2 \mathrm{H}^{+}+2 \mathrm{e}^{-} \rightarrow \mathrm{H}_{2} \uparrow \quad$ (reaksi reduksi)

Korosi yang terjadi pada suatu reaksi oksidasi disebut reaksi anodik ( terjadi penambahan muatan positif ), sedangkan korosi yang terjadi pada suatu reaksi reduksi disebut reaksi katodik ( terjadi pengurangan muatan positif ). Jadi proses korosi memerlukan sepasang reaksi elektrokimia anodik-katodik.

\subsection{Proses terjadinya korosi}

Korosi dapat dikatakan sebagai suatu peristiwa elektrokimia antara logam dengan lingkungannya. Secara sederhana, korosi dapat terjadi jika adanya sel, yaitu sel yang terdiri dari 4 faktor, yaitu:

1. logam yang menjadi anoda

2. logam yang menjadi katoda

3. adanya larutan elektrolit 


\section{4. adanya konduktor listrik}

\section{Anoda}

Adanya beda potensial menyebabkan timbulnya aliran arus listrik. Arus listrik mengalir dari potensial tinggi ke potensial rendah sedangkan elektron mengalir berlawanan dengan arah arus listrik.

Potensial anoda lebih negatif dari katoda sehingga elektron di anoda mengalir melalui kontak metalik ke katoda.

\section{Katoda}

Katoda yang menerima elektron membuat terjadinya reaksi katodik pada permukaan katoda, dimana elektron akan berada di permukaan katoda dan bereaksi dengan ion positif dari elektrolit.

Contohnya adalah pada reaksi elektron dengan $\mathrm{H}$ dalam membentuk molekul $\mathrm{H}_{2}$ yang berupa gelembung gas sehingga katoda akan terproteksi dari korosi.

\section{Larutan elektrolit}

Larutan elektrolit berfungsi sebagai media penghantar listrik. Agar terbentuk suatu loop maka dibutuhkan elektrolit guna menghantarkan arus dari anoda menuju katoda.

\section{Adanya kontak metalik}

Adanya kontak antara anoda dan katoda sehingga elektron dapat mengalir dari anoda menuju katoda. Elektron hanya bisa mengalir melalui kontak metalik. Elektron tidak bisa mengalir di dalam elektrolit.

Jika salah satu faktor tersebut tidak ada, maka korosi tidak akan terjadi. Proses terjadinya korosi digambarkan sebagai berikut :

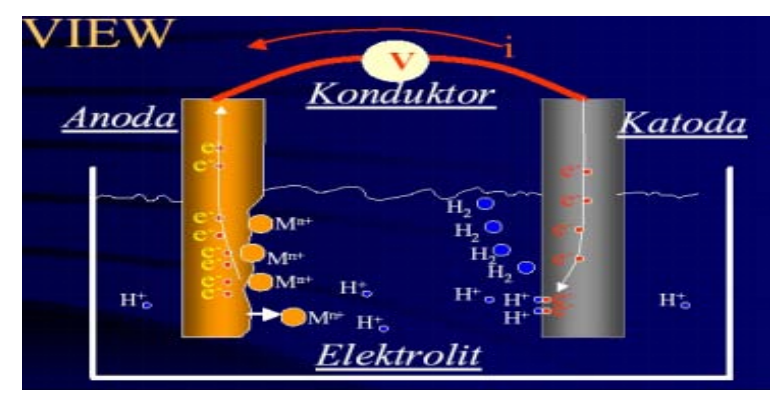

Gambar 2.1 Sel Korosi

Dua buah logam yang mempunyai potensial elektroda berbeda akan membuat dua kutub. Potensial yang lebih rendah akan menjadi kutub anoda dan potensial yang lebih tinggi menjadi kutub katoda. Ketika dua buah elektroda ini dihubungkan dalam larutan elektrolit yang sama, maka akan terjadi proses elektrokimia yaitu elektron mengalir dari anoda menuju katoda melalui konduktor listrik. Secara bersamaan dengan itu, terjadi aliran arus dari katoda ke anoda melalui elektrolit dan terjadi aliran arus secara tertutup yang berlangsung terus menerus yang akibatnya anoda tempat keluarnya arus menjadi terkorosi. Pada permukaan katoda elektron akan berikatan dengan ion $\mathrm{H}^{+}$untuk menjadi netral sebagai $\mathrm{H}_{2}$ dan elektron yang terlepas di permukaan anoda akan membuat ion-ion logam menjadi tidak stabil sehingga melarut kedalam larutan elektrolit. Proses terlepasnya ion logam inilah yang dinamakan korosi.

\section{a. Dampak korosi}

Dampak yang ditimbulkan korosi dapat berupa kerugian langsung dan kerugian tidak langsung.Kerugian langsung berupa terjadinya kerusakan pada peralatan, permesinan atau struktur bangunan. Sedangkan kerugian tidak langsung berupa terhentinya aktivitas produksi, karena terjadinya pergantian peralatan yang rusak akibat korosi, bahkan kerugian tidak langsung dapat berupa terjadinya kecelakaan yang menimbulkan korban jiwa, seperti kejadian runtuhnya jembatan akibat korosi, terjadinya kebakaran akibat kebocoran pipa gas karena korosi, dan meledaknya pembangkit tenaga nuklir akibat terjadinya korosi pada pipa uap.

\section{b. Penanggulangan Korosi}

Penanggulangan terhadap korosi dapat dilakukan dengan perlindungan mekanis dan perlindungan elektrokimia.

\section{c. Perlindungan mekanis}

Perlindungan mekanis dilakukan dengan mencegah agar permukaan logam tidak bersentuhan dengan udara dan air, misalnya dengan pengecatan dan pelapisan dengan logam lain (penyepuhan). Contoh lapisan pelindung yang digunakan untuk mencegah kontak langsung dengan $\mathrm{H}_{2} \mathrm{O}$ adalah lapisan cat, lapisan oli dan gemuk, lapisan plastik, dan lapisan dengan logam lain yang memiliki potensial elektrode yang lebih negatif.

\section{a. Perlindungan Elektrokimia}

\section{Sistem Proteksi Katodik}

Cara ini digunakan terutama untuk logam besi yang di tanam di dalam tanah. Prinsipnya 
adalah logam besi di hubungkan dengan logam lain yang bertindak sebagai anode dan besi sebagai katode. Jadi, logam yang digunakan untuk melindungi besi harus yang lebih mudah teroksidasi daripada logam besi, yaitu memiliki potensial reduksi yang lebih negatif daripada besi. Umumnya digunakan logam Magnesium (Mg).Logam alkali tidak dapat di gunakan karena reaktif.Logam alumunium (Al) dan seng (Zn) tidak dapat digunakan karena oksida logam tersebut $\left(\mathrm{Al}_{2} \mathrm{O}_{3}\right.$ atau $\left.\mathrm{ZnO}\right)$ akan menghambat proses oksidasi berikutnya dengan cara menutupi permukaan logam.

Pipa besi misalnya untuk air atau minyak yang ditanam di dalam tanah harus dilindungi. Untuk mencegah korosi pada pipa-pipa ini batang logam yang lebih aktif, seperti batang Magnesium (Mg) atau seng ( $\mathrm{Zn}$ ) ditanam di dekat pipa dan di hubungkan dengan kawat, batang magnesium akan mengalami oksidasi dan Mg yang rusak dapat diganti dalam jangka waktu tertentu sehingga dengan demikian pipa yang terbuat dari besi itu terlindung dari korosi. Korosi besi ini juga dapat dicegah dengan menghubungkan besi tersebut dengan kutub negatif sumber listrik.

Proteksi katodik juga merupakan teknik penanggulangan korosi komponen baja jembatan, khususnya pada bagian tiang pancang pipa baja yang berada dalam lingkungan air dan atau tanah karena pada bagian tersebut relatif sulit dilakukan teknik penanggulangan korosi. Dengan teknik yang lebih murah yaitu pengecatan.

Pada prinsipnya, korosi terjadi karena adanya aliran elektron dari bagian tiang pancang pipa baja (anoda) yang diikuti dengan perubahan logam menjadi ion logam (karat) ke bagian tiang pancang pipa baja lain yang karena kualitas baja atau kondisi lingkungannya menjadi katoda. Pada proteksi katodik, terjadinya kerusakan baja akibat aliran elektron dari anoda ke katoda ditanggulangi dengan memberikan pasokan elektron secukupnya pada seluruh struktur baja yang dilindungi atau dengan kata lain menjadikan seluruh struktur baja tersebut menjadi katoda yang kaya akan elektron. Dilihat dari cara memasok elektron, proteksi katodik terbagi dalam dua cara, yaitu:

\section{a. Metoda anoda korban (sucricifial anoda)}

Yaitu pasokan elektron dilakukan dengan cara menghubungkan pipa baja dengan logam lain sebagai anoda korban yang memiliki potensial lebih rendah. Pada cara ini terjadi aliran elektron dari logam dengan potensial yang lebih rendah ke pipa baja yang potensialnya lebih tinggi.

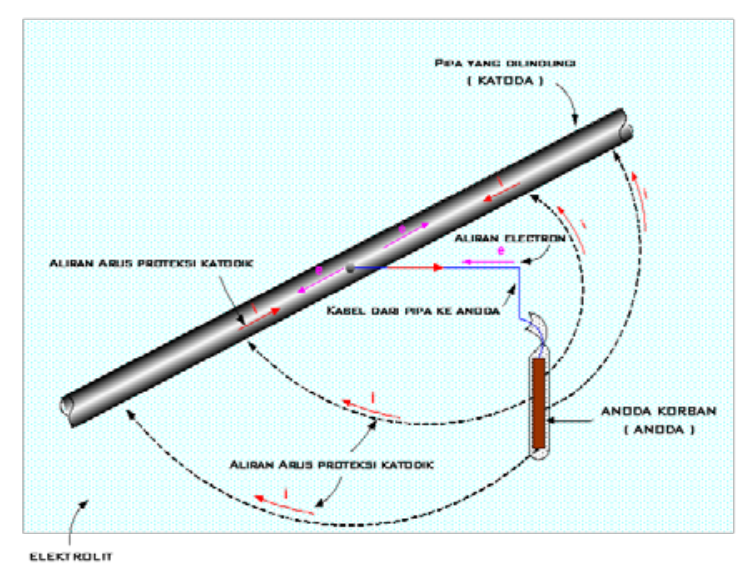

Gambar 2.2 Skema anoda korban

\section{b. Metoda arus terpasang (impressed current)}

Yaitu pasokan elektron dilakukan dengan cara menghubungkan pipa dengan katoda pada suatu sumber listrik. Metoda ini menggunakan sumber arus searah dari luar, misalnya transformer rectifier, DC generator, dan lainlain. Arus listrik pada sistem ini dialirkan ke permukaan logam yang diproteksi melalui anoda pembantu, misalnya anoda graphite, baja, platina, dan besi tuang. Keuntungan besar dari metoda arus terpasang adalah bahwa sistem ini dapat menggunakan anoda inert atau anoda yang tahan karat seperti platina dan karbon.

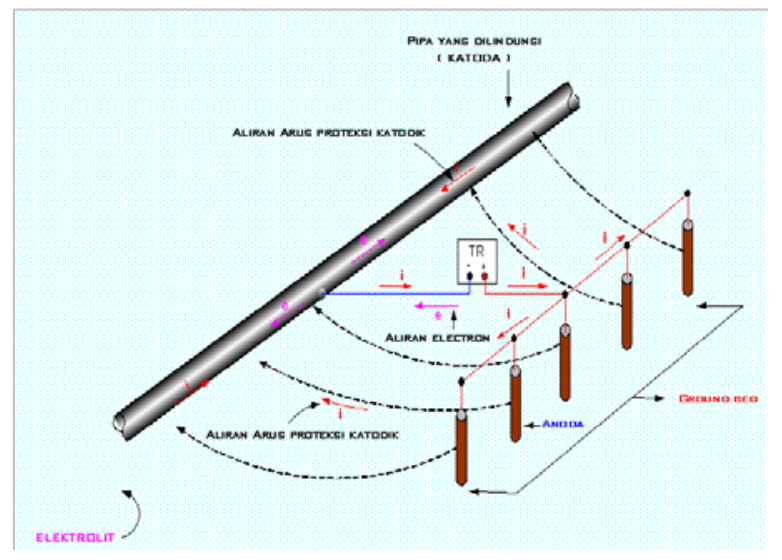

Gambar 2.3 Skema arus tanding impressed current (IC)

\section{a. Perbandingan Kedua Sistem Proteksi Katodik}

Prinsip proteksi katodik untuk kedua sistem adalah sama, yaitu menurunkan potensial logam ke daerah imun menurut diagram $\mathrm{pH}-$ potensial. 
Tetapi karena sistem struktur yang diproteksi umumnya sangat kompleks, maka perlu dilakukan pemilihan sistem aplikasi proteksi katodik yang paling baik untuk digunakan. Berikut perbandingan kedua sistem tersebut.

\subsubsection{Sistem Anoda Korban}

Keuntungan :

- Tidak perlu tenaga listrik dari luar.

- Pemasangan relatif mudah

- Tidak ada bahaya interaksi.

- Murah untuk struktur kecil.

- Daerah padat struktur.

- Bahaya over-proteksi ringan.

- Distribusi arus merata.

- Tidak perlu pemeliharaan, kecuali inspeksi rutin.

- $\quad$ Tidak perlu biaya operasi.

Kerugian :

- Keluaran arus anoda terbatas, pada hal makin lama makin diperlukan arus lebih besar karena degradasi lapis lindung.

- Tidak efektif untuk lingkungan dengan resistivitas lingkungan tinggi.

- Untuk struktur yang besar diperlukan anoda banyak jumlahnya.

- Keluaran arus tidak dapat dikontrol, namun self regulating.

\subsubsection{Sistem Arus Tanding}

Keuntungan :

- $\quad$ Sistem instalasi dapat memproteksi struktur yang besar.

- Sistem dapat didesain yang beubah dengan waktu.

- Keluaran arus proteksi mudah diatur sesuai dengan keperluan.

- Sistem dapat didesain untuk masa guna lebih dari 20 tahun.

- Biaya awal lebih murah.

Kerugian :

- Kemungkinan ada interaksi terhadap struktur lain

- Tegantung dari keberadaan sumber listrik luar.

- $\quad$ Perlu pemeliharaan dan inspeksi rutin yang cermat.

- Perlu biaya operasi.

- Dapat terganggu oleh kegagalan catu daya listrik.

\section{METODE PENELITIAN}

Dalam penulisan proyek akhir ini menggunakan metode-metode yang dapat membantu, metode itu antara lain.

1. Metode Studi Literature

Dengan melakukan pencarian informasi melalui manual book di PT PGN SOLUTION dan sumber-sumber yang berkaitan dengan permasalahan yang dibahas.

2. Metode Studi Lapangan

Pada metode Studi Lapangan ini dilakukan dengan cara datang langsung ke lapangan untuk melakukan proses pengamatan langsung pada pipa gas dengan didampingi operator PT PGN SOLUTION.

\subsection{Kerangka Pemecahan Masalah}

1. Langkah-langkah penyelesaian masalah Berdasarkan studi literature dan studi lapangan, maka dapat dipastikan gangguan yang terjadi pada pipa gas PGN adalah korosi. Untuk memudahkan dalam memahami isi dari penelitian ini, maka dibuat flowchart sebagai langkah langkah penyelesaian masalah :

1. Mulai

Menerangkan bahwa suatu pekerjaan dimulai. Sebagai langkah awal pekerjaan akan dimulai.

2. Studi Literature

Melakukan pencarian informasi melalui manual book di PT PGN SOLUTION dan sumber-sumber yang berkaitan dengan permasalahan yang dibahas.

3. Studi Lapangan

Melakukan proses pengamatan langsung kelapangan bersama operator lapangan.

4. Kesimpulan

Kesimpulan ini merupakan inti dari hasil penelitian yang dilakukan.

5. Selesai

Menerangkan bahwa pekerjaan telah selesai.

\subsection{Teknik Pengumpulan Data}

Untuk mendapatkan data yang maksimal dari penelitian ini, maka diperlukan teori berupa informasi dan keterangan data-data akurat sebagai landasan penulisan dan penyusunannya. Data tersebut diperoleh dengan metode sebagai berikut : 
1. Metode Pengamatan Tidak Langsung

Metode ini melakukan pengamatan secara tidak langsung yaitu teori berupa informasi dan keterangan yang didapat dari buku dan internet.

2. Metode Pengamatan Langsung

(Observation Methode)

Melakukan pengamatan langsung pada Blades kompresor di PT PGN SOLUTION.

3. Metode Wawancara (Interview Methode)

Mengajukan pertanyaan kepada staf ahli dan pegawai dari PT PGN SOLUTION.

4. Metode studi literature/kepustakaan (Library Methode )

Mempelajari manual book dari perpustakaan PT PGN SOLUTION, Procedure atau sumber-sumber referensi lain yang berkaitan dengan permasalahan yang akan dibahas.

\section{Teknik Pengolahan Data}

Dalam teknik pengolahan data ini menjabarkan tentang pengolahan data yang didapat dari metode pengumpulan data untuk mengerjakan penelitian ini. Adapun langkah langkah pengolahan data sebagai berikut ;

1. Permasalahan yang terjadi pada pipa gas di PT PGN SOLUTION. (Korosi).

2. Usaha penanggulangan terhadap permasalahan tersebut.

3. Mengkombinasikan antara data yang didapat secara langsung dan tidak langsung.

\section{Analisis dan Kesimpulan}

Tahap ini merupakan tahap akhir yang merupakan analisis dari hasil pengamatan serta kesimpulan dan saran mengenai pekerjaan yang dilakukan.

\section{HASIL DAN PEMBAHASAN}

\subsection{Penanggulangan korosi}

\section{Sistem proteksi katodik}

Cara ini digunakan terutama untuk logam besi yang di tanam di dalam tanah. Prinsipnya adalah logam besi di hubungkan dengan logam lain yang bertindak sebagai anoda dan besi sebagai katoda. Jadi, logam yang digunakan untuk melindungi besi harus yang lebih mudah teroksidasi dari pada logam besi, yaitu memiliki potensial reduksi yang lebih negatif dari pada besi. Umumnya digunakan logam Magnesium (Mg). Logam alkali tidak dapat di gunakan karena reaktif. Logam alumunium (Al) dan seng
(Zn) tidak dapat digunakan karena oksida logam tersebut $\left(\mathrm{Al}_{2} \mathrm{O}_{3}\right.$ atau $\left.\mathrm{ZnO}\right)$ akan menghambat proses oksidasi berikutnya dengan cara menutupi permukaan logam.

\section{Prinsip proteksi katodik}

Dalam keadaan terproteksi katodik, logam yang diproteksi dialiri arus listrik melalui anoda dan lingkungan menuju logam, atau logam dibanjiri dengan elektron.

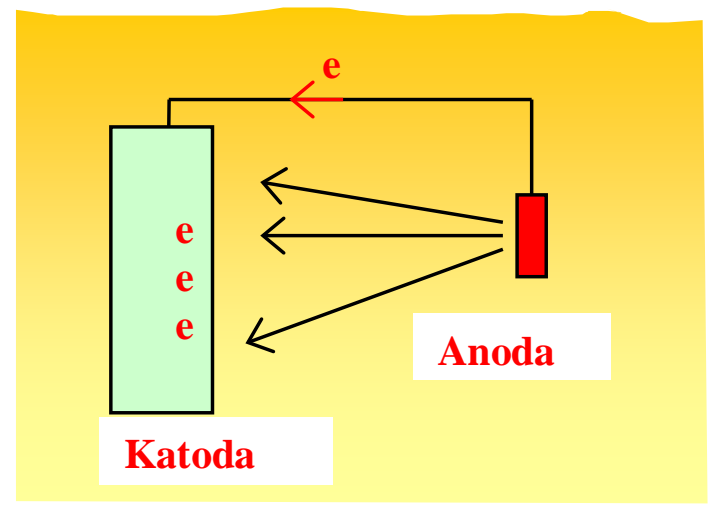

Gambar 4.1 skema proses anoda korban

Bila suatu logam/paduan terkorosi ada bagian-bagian yang bersifat sebagai anoda di mana korosi terjadi, dan ada bagian-bagian yang bersifat sebagai katoda di mana korosi tidak terjadi. Korosi terjadi di mana arus listrik meninggalkan logam menuju elektrolit, dan sebaliknya korosi tidak terjadi di mana arus listrik masuk ke dalam logam.

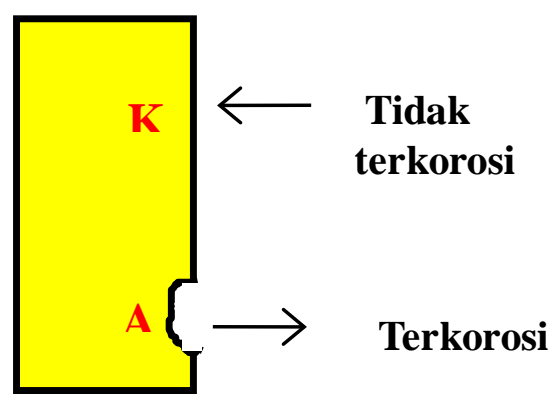

Gambar 4.2 skema terjadinya korosi pada logam

3. Metode anoda korban (sucricifial anoda)

Sistem anoda korban secara alami menghasilkan arus DC yang dihasilkan dari pasangan galvanik antara logam yang di lindungi dan anoda korban itu sendiri. Material yang digunakan sebagai anoda

Korban adalah logam yang secara alami memiliki potensial yang lebih negatif. 
Untuk memproteksi katodik diperlukan arus yang dialirkan melalui elektrolit ke arah logam yang diproteksi, supaya potensial logam turun dan logam menjadi lebih stabil.

Untuk menurunkan potensial dari logam/paduan yang akan diproteksi diperlukan sumber arus listrik searah. Sumber arus searah ini dapat diperoleh dari suatu reaksi galvanik yaitu bila logam yang diproteksi dihubungkan dengan logam yang lebih reaktif dalam suatu elektrolit.

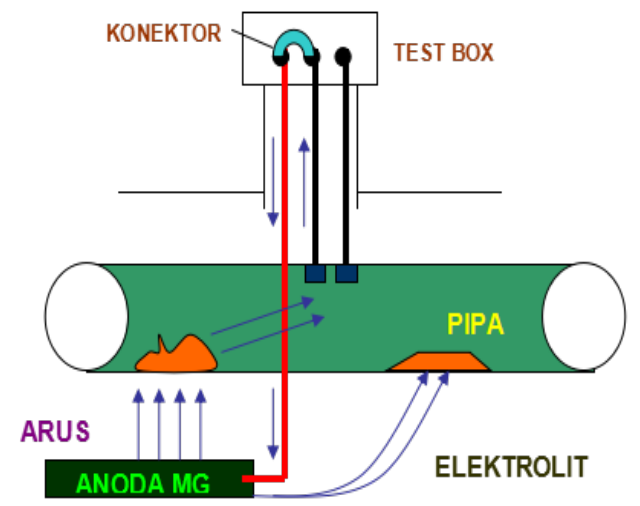

Gambar 4.3 prinsip kerja sistem anoda korban

Reaksi galvanik dapat terjadi bila logam yang diproteksi dihubungkan dengan logam yang lebih aktif. Seri emf adalah deret urutan potensial standar dari logam-logam murni pada kondisi standar, yaitu pada suhu $25^{\circ} \mathrm{C}$. Deret galvanik adalah urutan potensial dari logam atau paduan dalam lingkungan tertentu.

Seri emf (electromotive force) adalah nilainilai termodinamik, atau teoritis yang dalam praktek di lapangan tidak kita jumpai. Manfaatnya tentu ada, yaitu untuk meramalkan saja.

Tabel 4.1 Deret emf

\begin{tabular}{|c|c|}
\hline Jenis logam & Potensial, V(SHE) \\
\hline Au/Au3+ & 1,50 \\
\hline $\mathbf{P t} / \mathbf{P t}++$ & 1,20 \\
\hline Hg/Hg++ & Mulia \\
\hline $\mathrm{Cu} / \mathrm{Cu}++$ & 0,85 \\
\hline $\mathbf{H} / \mathbf{H}^{+}$ & 0,337 \\
\hline $\mathbf{P b} / \mathbf{P b}++$ & 0,00 \\
\hline $\mathrm{Ni} / \mathrm{Ni}++$ & $-0,126$ \\
\hline $\mathbf{F e} / \mathbf{F e}++$ & $-0,25$ \\
\hline $\mathrm{Zn} / \mathbf{Z n + +}$ & $-0,44$ \\
\hline Al/Al3+ & $-0,76$ \\
\hline Mg/Mg++ & $-1,66$ \\
\hline & 2,37 \\
\hline
\end{tabular}

Seri emf (electromotive force) adalah nilainilai termodinamik, atau teoritis yang dalam praktek di lapangan tidak kita jumpai. Manfaatnya tentu ada, yaitu untuk meramalkan saja.

Tabel 4.2 Deret Galvanik

\begin{tabular}{|ll|}
\hline $\begin{array}{l}\text { Mulia } \\
\text { pasif }\end{array}$ & Baja tahan karat 304 \\
& Titanium \\
& Nikel pasif \\
& Tembaga \\
& Kuningan \\
& Aluminium bronze \\
& Nikel aktif \\
& Timah \\
& Baja tahan karat 304 aktif \\
& Besi tuang (cor) \\
& Baja giling \\
& Baja lunak \\
& Aluminium \\
& Seng \\
& Paduan magnesium \\
& Magnesium \\
Aktif & \\
& \\
& \\
\hline
\end{tabular}

Deret galvanik adalah urutan potensial dari logam atau paduan dalam lingkungan tertentu.

Proteksi katodik dengan reaksi galvanik ini disebut metoda galvanik atau metoda anoda korban (sacrificial anode method). Pada metoda ini, logam yang lebih aktif akan bersifat sebagai anoda dan terkorosi, dan elektron yang ditinggalkan pada logam akan mengalir melalui konduktor ke logam yang diproteksi atau katoda.

Tingkat proteksi ditentukan oleh besarnya arus listrik yang dapat diberikan oleh anoda. Makin besar arus listrik yang dihasilkan anoda makin tinggi tingkat proteksinya. Secara prinsip, arus listrik akan makin besar bila anoda makin besar atau beda potensial antara logam yang diproteksi dan anoda makin besar. Dari deret emf atau deret galvanik dapat dilihat bahwa logam-logam magnesium, aluminium dan seng merupakan logam-logam yang berpotensi sebagai anoda, dan dalam praktek memang logam-logam ini banyak digunakan. 


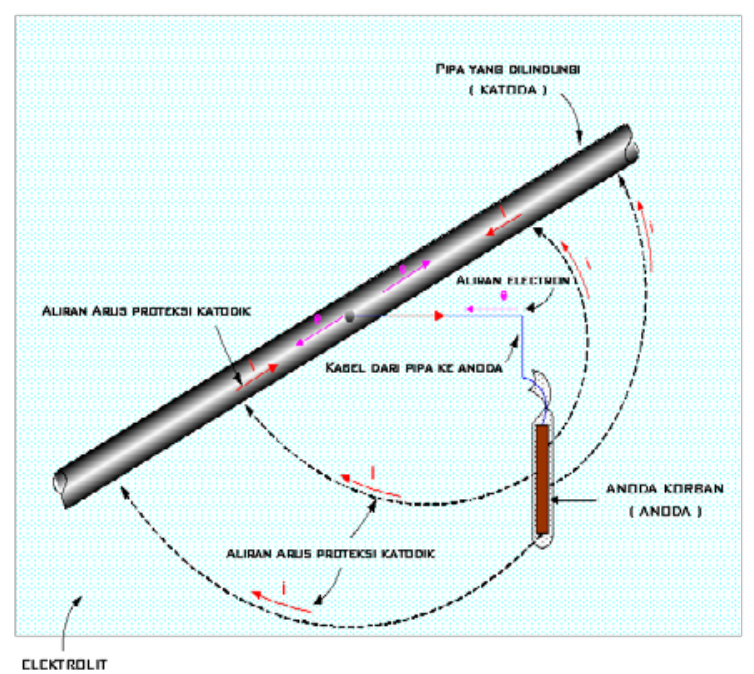

Gambar 4.4 skema catodik protection (anoda korban)

\section{Metode Arus Tanding (Impressed Curent)}

Logam yang akan diproteksi dihubungkan dengan muatan negatif sehingga sebagai katoda, sedangkan logam lain sebagai groundbed dihubungkan dengan muatan positif dan berfungsi sebagai anoda. Katoda dan anoda dihubungkan dengan kawat penghantar melalui sumber listrik arus searah (DC).

Dengan cara ini arus mengalir dari anoda melalui elektrolit (dalam tanah) ke logam lain sebagai katoda dan elektron akan mengalir dari anoda ke katoda melalui kawat penghantar listrik, sehingga pipa terhindar dari korosi.

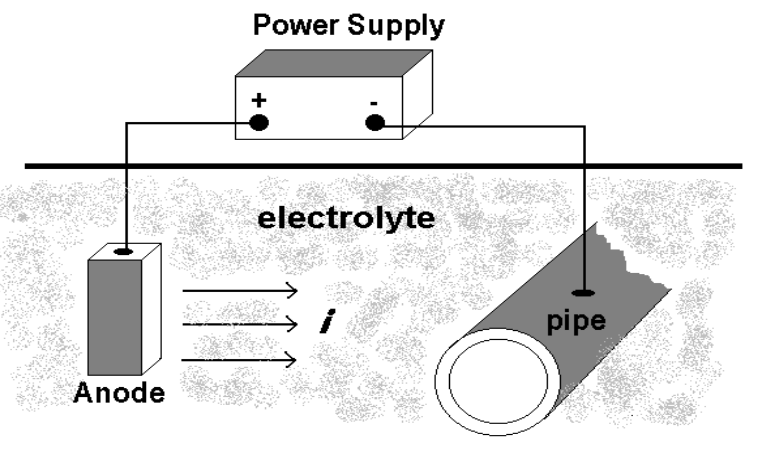

Gambar 4.5 Skema Proteksi Katodik Arus Tanding.

Dalam sistem arus tanding, arus listrik searah berasal dari arus luar, umumnya menggunakan rectifier atau dengan solar cell melalui aki, atau motor listrik yang menghasilkan arus searah, yang ditampung dalam aki lebih dulu untuk memperoleh arus listrik yang mulus tanpa ripple.
Arus listrik dari sumber listrik tersebut dialirkan melalui kabel, terus ke anoda yang dikubur atau direndam dalam elektrolit. Pada dasarnya semua bahan yang bersifat konduktor listrik dapat digunakan sebagai anoda; logam, keramik atau plastik yang konduktif dapat digunakan. Akan tetapi karena arus listrik searah yang dialirkan pada umumnya cukup besar (dalam orde sampai ratusan Ampere), maka segi teknis dan ekonomis harus diperhatikan.

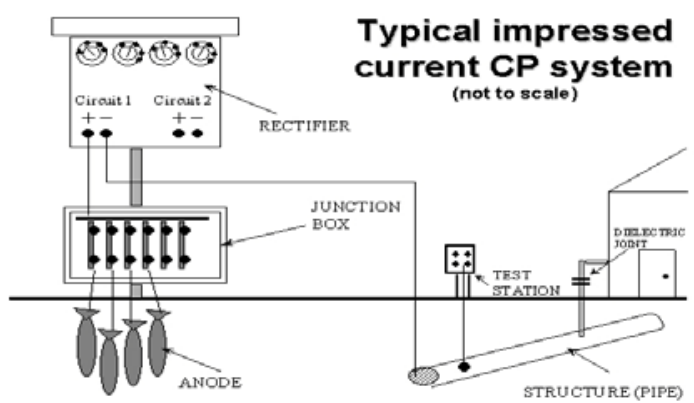

Gambar 4.6 rangkaian proteksi katodik arus tanding

\section{Perhitungan Desain Catodik Protection (Anoda Korban)}

Data yang perlu untuk perhitungan

- $\quad$ Ukuran struktur pipa (D \& L)

- Resistivitas tanah

- $\quad$ Coating pipa

- Keperluan arus proteksi

- $\quad$ Umur proteksi

- Jenis Anoda

Kebutuhan arus proteksi

Untuk mengetahui jumlah arus proteksi yang dapat melindungi pipa dari serangan korosi dengan mengasumsikan bahwa 5\% dari permukaan pipa mengalami cacat coating selama pipa tersebut dioperasikan (min 20 tahun), diperlukan arus proteksi dari anoda sebesar $5 \mathrm{~mA}$ untuk memproteksi $1 \mathrm{~m}^{2}$ pipa yang mengalami cacat coating.

Data untuk perhitungan :

\begin{tabular}{|l|l|}
\hline \multicolumn{1}{|c|}{ Jenis pipa baja } & \multicolumn{1}{c|}{$\begin{array}{c}\text { Steel API 5L } \\
\text { Grade B }\end{array}$} \\
\hline Panjang pipa (L) & $5.340 \mathrm{~m}$ \\
\hline Diameter luar (OD) & $6.625 \mathrm{inch}=$ \\
& $0.1683 \mathrm{~m}$ \\
\hline Tebal dinding pipa & $7,11 \mathrm{~mm}$ \\
\hline Jenis coating & Coaltar Enamel \\
\hline Konduktansi coating (g) & $0,0002 \mathrm{~S} / \mathrm{m}$ \\
\hline Tahanan tanah rata-rata & $2.227,83 \mathrm{ohm}-\mathrm{cm}$ \\
\hline
\end{tabular}


Langkah perhitungan :

1. Luas permukaan pipa

$$
A=\pi \times \mathrm{OD} \times \mathrm{L}
$$

$\mathrm{A}=3,14 \times 0,1683 \mathrm{~m} \times 5,340 \mathrm{~m}$

$\mathrm{A}=2.821,57 \mathrm{~m}^{2}$

Dimana :

$$
\begin{aligned}
\mathrm{A} & =\text { Luas permukaan pipa (m2) } \\
\boldsymbol{\pi} & =3,14 \\
\text { OD } & =\text { Diameter luar pipa (m) } \\
\mathrm{L} & =\text { Panjang pipa (m) }
\end{aligned}
$$

2. Kerusakan coating

$\mathrm{A}_{1}=$ Luas permukaan pipa yang cacat coating

$\left(\mathrm{m}^{2}\right)$ dengan asumsi kerusakan coating $=5 \%$

$\mathrm{A}_{1}=5 \% \times \mathrm{A}$

$\mathrm{A}_{1}=5 \% \times 2.821,57 \mathrm{~m}^{2}$

$\mathrm{A}_{1}=141,08 \mathrm{~m}^{2}$

\section{Kebutuhan arus proteksi}

Untuk melindungi coating pipa yang rusak di perlukan arus sebesar $5 \mathrm{~mA}$

$\mathrm{I}=5 \mathrm{~mA} / \mathrm{m}^{2} \times \mathrm{A}_{1}$

$\mathrm{I}=5 \mathrm{~mA} / \mathrm{m}^{2} \mathrm{x} 141,08 \mathrm{~m}^{2}$

$\mathrm{I}=705,4 \mathrm{~mA}$

Dengan :

$\mathrm{I}=$ kebutuhan arus proteksi (mA)

4. Ketahanan anoda

Data-data anoda adalah :

\begin{tabular}{|l|l|}
\hline \multicolumn{1}{|c|}{$\begin{array}{c}\text { Tahanan tanah rata- } \\
\text { rata }\end{array}$} & $\begin{array}{l}2.227,83 \text { Ohm- } \\
\mathrm{cm}\end{array}$ \\
\hline Kedalaman anoda (s) & $300 \mathrm{~cm}$ \\
\hline Jenis anoda & $\begin{array}{l}\text { Magnesium } \\
\text { grade A }\end{array}$ \\
\hline Berat anoda & $32 \mathrm{lb}$ \\
\hline Panjang anoda $\quad(l)$ & $50,80 \mathrm{~cm}$ \\
\hline Diameter anoda (d) & $12,70 \mathrm{~cm}$ \\
\hline Potensial anoda & $1550 \mathrm{mV}$ \\
\hline $\begin{array}{l}\text { Konstanta untuk anoda } \\
\text { magnesium }\end{array}$ & 0,116 \\
\hline $\begin{array}{l}\text { Konstanta untuk anoda } \\
\text { zinc }\end{array}$ & 0.0424 \\
\hline
\end{tabular}

Menggunakan rumus dwigh formula (di pasang horisontal)

$$
\begin{aligned}
& R h=\frac{\rho}{2 \cdot \pi \cdot l}\left(\ln \frac{4 \cdot l^{2}+4 \cdot l \sqrt{S^{2}+l^{2}}}{d \cdot S}+\frac{S}{l}-\frac{\sqrt{S^{2}+l^{2}}}{l}-1\right) \\
& R h=\frac{2 \cdot 227,83}{2 \cdot \pi \cdot 50,8}\left(\ln \frac{4 \cdot 50,8^{2}+4 \cdot 50,8 \sqrt{300^{2}+50,8^{2}}}{12,7.300}+\frac{300}{50 \cdot 8}-\frac{\sqrt{300^{2}+50,8^{2}}}{50,8}-1\right) \\
& =6,98326(2,9411+5,9055-5,9896-1) \\
& =12,97 \mathrm{Ohm} .
\end{aligned}
$$

Dengan :

$\mathrm{Rh}=$ Tahanan dari tiap anoda (ohm)

$\mathrm{p}=$ Tahanan tanah rata-rata (ohm-cm)

$\mathrm{L}=$ Panjang anoda $(\mathrm{cm})$

$\mathrm{S}=300 \mathrm{~cm}$

$\mathrm{d}=$ Diameter anoda $(\mathrm{cm})$

$\boldsymbol{\pi}=3,14$

$\ln =$ Natural Logaritma

\section{Driving voltage}

$$
\begin{aligned}
\text { Dv } & =(\text { pot. anoda })-(\text { pot. proteksi }) \\
& =1550-850 \\
& =700 \mathrm{mV}
\end{aligned}
$$

6. Jumlah arus keluar dari tiap anoda

$$
\begin{aligned}
\text { Ioa } & =\frac{\mathrm{Dv}}{\mathrm{Rh}} \\
& =\frac{700}{12,97} \\
& =53,98 \mathrm{mAmp}
\end{aligned}
$$

Dengan:

Ioa = Arus keluar dari tiap anoda (mAmp)

Dv =Perbedaan potensial (mVolt), hal ini tergantung jenis anoda

$\mathrm{Rh}=$ Tahanan tiap anoda Min. potensial proteksi adalah $-850 \mathrm{mVolt}$

7. Jumlah anoda yang diperlukan

$$
\begin{aligned}
\mathrm{n} & =\frac{I}{I o a} \\
& =\frac{705,4}{53,98} \\
& =13,07 \text { buah }
\end{aligned}
$$

Dimana :

$$
\begin{array}{ll}
\mathrm{n} & =\text { Jumlah anoda (buah) } \\
\mathrm{I} & =\text { Kebutuhan arus proteksi (mAmp) } \\
\text { Ioa } & =\text { Arus keluar dari tiap anoda (mAmp) }
\end{array}
$$

8. Umur tiap anoda

$$
\begin{aligned}
& U=\frac{0,116 \times \text { Wa } \times \text { eff } \times \text { Uf }}{\text { Ioa }} \\
& U=\frac{0,116 \times 32 \times 0,50 \times 0,85}{0,054} \\
& U=29,22 \text { tahun. }
\end{aligned}
$$

Dimana :

$$
\begin{aligned}
& \mathrm{Wa}=\text { Berat anoda } \quad=32 \mathrm{lb} \\
& \text { eff }=\text { Efisiensi } \quad=50 \% \\
& \text { Uf }=\text { Utilization factor } \quad=85 \% \\
& \text { Ioa }=\text { Arus keluar tiap anoda }=0,054 \mathrm{Amp} \\
& \text { 9. Jumlah anoda untuk desain umur pipa } 20 \\
& \text { tahun } \\
& n 20=\frac{20}{U} \times n \\
& =\frac{20}{29,22} \times 13,07 \\
& =8,94 \text { buah (di bulatkan menjadi } 9 \text { buah) }
\end{aligned}
$$


Dimana :

$\mathrm{n}_{20}=$ Umur pipa untuk 20 tahun

$\mathrm{U}=$ Umur tiap anoda

$\mathrm{n}$ = Jumlah anoda

10. Tahanan dari pipa

$\mathrm{R}=\frac{0,135}{\pi \times O D \times t}$

$\mathrm{R}=\frac{0,135}{3,14 \times 0,1683 \times 7,11}$

$\mathrm{R}=0,04 \mathrm{Ohm} / \mathrm{km}$

Dimana :

$\mathrm{R}=$ Tahanan dari pipa (ohm $/ \mathrm{km})$

$\mathrm{D}=$ Diameter luar pipa (m)

$\mathrm{t}=$ tebal dinding pipa (mm)

11. Konduktivitas lapis lindung

$\mathrm{G}=1000 \times \pi \times \mathrm{D} \times \mathrm{g}$

$G=1000 \times 3,14 \times 0,1683 \times 0,0002$

$\mathrm{G}=0,11 \mathrm{Mho} / \mathrm{km}$

Dimana :

$\mathrm{G}=$ konduktivitas coating

$\mathrm{OD}=$ diameter luar pipa

$\mathrm{g}=$ konduktansi coating $(0,0002)$

12. Jangkauan proteksi pipa

Jangkauan proteksi pipa untuk 1 anoda

Jadi untuk :

$\mathrm{Ex}=850 \mathrm{mVolt}$

$\mathrm{Eo}=1200 \mathrm{mVolt}$

$\mathrm{X}=-\ln (\mathrm{Ex} / \mathrm{Eo}) /(\sqrt{R+G})$

$X=-\ln (850 / 1200) /(\sqrt{0,04+0,11})$

$\mathrm{X}=5,2 \mathrm{~km}$

Dimana :

Ex $=$ Potensial minimal pipa terproteksi pada jarak x km (mVolt)

Eo $=$ Potensial pipa terproteksi dekat anoda (mVolt)

$\mathrm{X}=$ Jangkauan anoda memproteksi pipa $(\mathrm{km})$

$\mathrm{R}=$ Tahanan pipa $(\mathrm{Ohm} / \mathrm{km})$

$\mathrm{G}=$ Konduktifitas coating (Mho/km)

6. Teknik Pengukuran Proteksi Katodik Pada sistem anoda korban

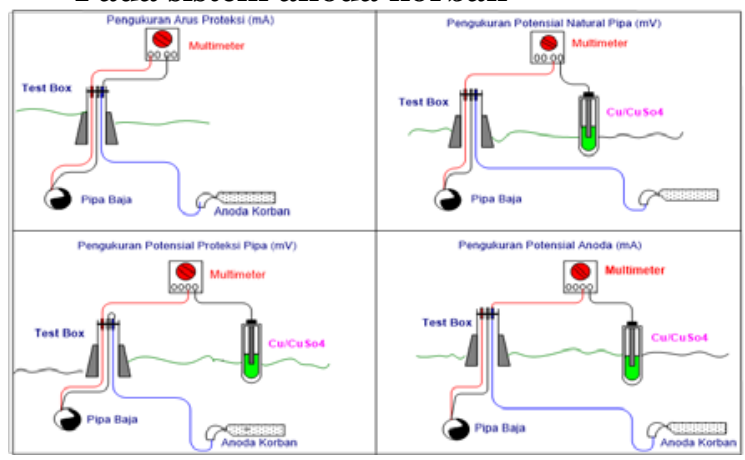

Gambar 4.7 Pengukuran pada Sistem Anoda Korban
Pengukuran dan pengecekan dengan menggunakan alat multimeter dan HalfCell $(\mathrm{Cu} / \mathrm{CuSO} 4)$ yang meliputi :

- $\quad$ Potensial Pipa Terproteksi (-mV)

- Potensial Pipa Tidak Terproteksi / Natural Pipa (-mV)

- $\quad$ Potensial Anoda (-mV)

- $\quad$ Arus Proteksi Anoda (mAmp)

Dengan menggunakan Reference Electrode yang dihubungkan ke multimeter, maka nilai yang ditunjukkan oleh multimeter adalah nilai potensial pipa terhadap tanah yang memperlihatkan pipa terproteksi.

Pastikan sistem proteksi katodik beroperasi pada potensial proteksi yang sesuai yaitu maksimum -850 mv dan minimum -2000 mv.

1. Pengukuran Potensial Pipa Terproteksi

Untuk mengukur potensial pipa, gunakan sebuah digital multi meter yang mempunyai tahanan dalam yang tinggi dan elektroda pembanding $\mathrm{Cu} / \mathrm{CuSO} 4$. terminal negative dihubungkan ke elektroda $\mathrm{Cu} / \mathrm{CuSO} 4$ sedangkan terminal positif dihubungkan ke Pipa atau struktur yang diproteksi.

Gambar 4.8 Pengukuran Potensial Pipa Terproteksi.

2. Pengukuran Potensial Natural Pipa

Untuk pengukuran potensial natural pipa dilakukan hal yang sama seperti butir (1). Dengan memutuskan sementara hubungan anoda dengan pipa.

Gambar 4.9 Pengukuran Potensial Natural Pipa 


\section{Pengukuran Potensial Anoda}

Untuk mengukur potensial anoda, gunakan sebuah digital multi meter yang mempunyai tahanan dalam yang tinggi dan elektroda pembanding $\mathrm{Cu} / \mathrm{CuSO} 4$. terminal negative dihubungkan ke elektroda $\mathrm{Cu} / \mathrm{CuSO} 4$ sedangkan terminal positif dihubungkan ke anoda.

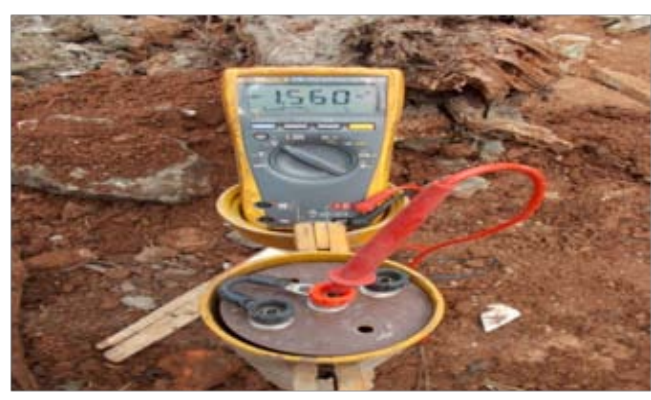

Gambar 4.10 Pengukuran Potensial Anoda.

4. Pengukuran Poptensial Arus Proteksi

Untuk pengukuran arus proteksi anoda dengan mengubah volt ke ampere pada multimeter, terminal negative dihubungkan ke pipa dan terminal positif ke anoda.

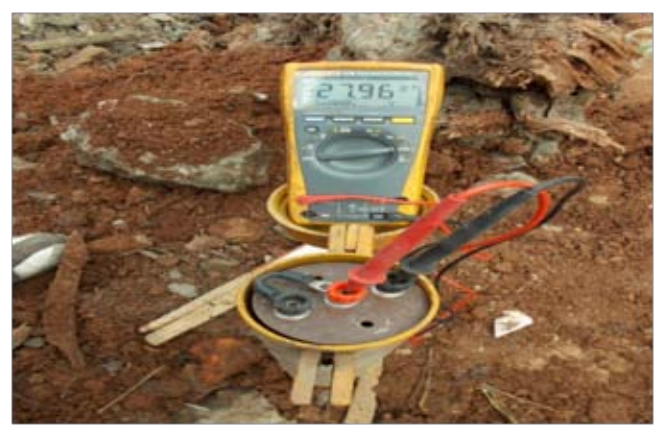

Gambar 4.11 Pengukuran Potensial Arus Proteksi

\section{KESIMPULAN}

a. Usaha Penanggulangan adanya korosi pada pipa gas yaitu dengan metode proteksi katodik (anoda korban) Cara ini digunakan terutama untuk logam besi yang di tanam di dalam tanah. Prinsipnya adalah logam besi di hubungkan dengan logam lain yang bertindak sebagai anoda dan besi sebagai katoda. Jadi, logam yang digunakan untuk melindungi besi harus yang lebih mudah teroksidasi daripada logam besi, yaitu memiliki potensial reduksi yang lebih negatif dari pada besi. b. Bila kita akan memasang sistem proteksi katodik pada jaringan pipa, maka tahap awal yang harus dilaksanakan adalah melakukan desain, sehingga sistem proteksi katodik yang terpasang dapat sesuai dengan data dan situasi serta kondisi dimana pipa akan dipasang

\section{REFERENSI}

[1] PERUSAHAAN GAS NEGARA (PERSERO) Divisi Pasokan Gas dan Operasi,"Konstruksi Sistem Proteksi Katodik", 1995, Jakarta

[2] BS 7361-1:1991 - Cathodic Protection

[3] Manual book instruksi kerja (IK) PT PGN SOLUTION

[4] Threthewey.J.Chamberlain, 1991, Korosi untuk mahasiswa dan Rekayasawan, Gramedia Pustaka Utama, Jakarta

[5] Svehla G, 1990, Buku teks Analisis Anorganik kualitatif Makro dan semi makro, Kalman Media Pustaka, Jakarta

[6] ASTM International, 2004, Standard Practice for Laboratory Immersion Corrosion Testing of Metals, Harbor Drive, United States

[7] Mars, G. Fontana,Norbert, D, Greeene, 1983, Corrosion Engineering, Mc GrawHill Book Company,Tokyo Japan

[8] Jurnal ENGINE Vol 1 No.1 Mei 2017, PP 1-10 e-ISSN : 2579-7433, Pengaruh Korosi Terhadap Kekuatan Tarik Macaroni Tubing P110 $1.9000^{11}$ x 4,19 lbs/ft, Jakarta

[9] Jurnal Ilmiah dan Teknologi Vol 1,1X/No.24/Juni/2013, Perancangan Sistem Proteksi Katodik (CP) Anoda Karbon pada Pipa Baja Studi Kasus Pipa PGN yang berada di PT. Nippon SOKUGAI Indonesia, Jakarta

[10] NACE International, The Corrosion Society., 1999, Standard Recommended Practice Preparation, Installation, Analysis, and Interpretation of Corrosion Coupons in Oilfield Operations, Houston, Texas. 